\title{
Pågående intervensjonsstudie for ungdom med gjentatt villet egenskade
}

\author{
Ved Egil Haga og Lars Mehlum
}

\begin{abstract}
I Oslo og Akershus gjøres nå en intervensjonsstudie som henvender seg til ungdom (12-18 år) med gjentatt villet egenskade. Prosjektet gjennomføres ved Nasjonalt senter for selvmordsforskning og -forebygging (NSSF) i samarbeid med Oslo universitetssykehus. Vi ønsker her å gi oppdatert informasjon om status for prosjektet.
\end{abstract}

Inklusjon av pasienter til en pilotstudie startet i januar 2007, og man har siden sommeren 2008 inkludert pasienter til en randomisert, kontrollert studie. 80 pasienter vil delta i denne, halvparten randomisert til dialektisk atferdsterapi (DBT) og den andre halvparten til "treatment-as-usual” (TAU). Begge gruppene får behandling i 20 uker, og behandlingen gis ved barne- og ungdomspsykiatriske poliklinikker (BUP-er) i Oslo og Akershus. Data samles inn f $\varnothing \mathrm{r}$ behandlingsoppstart og deretter under behandling, ved behandlingsslutt samt 12 måneder etter behandlingsslutt.

Prosjektet drives av en prosjektgruppe som består av Lars Mehlum (prosjektleder), Berit Grøholt, Anita Tørmoen (stipendiat), Maria Ramberg (stipendiat) og Egil Haga (prosjektkoordinator), mens en rekke andre medarbeidere internt og eksternt bidrar med ulike typer innsats. Prosjektet har tidligere blitt omtalt i Suicidologi (Larsson et al., 2006) mens det ennå var under planlegging.

\section{Bakgrunn}

Bakgrunnen for prosjektet er dokumentert forekomst av villet egenskade (med eller uten suicidal intensjon) i ungdomsgruppen (Ystgaard et al., 2003) og behovet for å tilby effektive behandlingsmetoder til behandlingstrengende ungdommer med gjentatt selvskading. Dialektisk atferdsterapi (DBT) ble utviklet av Marsha Linehan for behandling av voksne kvinner med selvskading/suicidalatferd og borderline personlighetsforstyrrelse. Det er så utviklet en ungdomsversjon (DBTA) som bl.a. har et kortere behandlingsforl $\varnothing \mathrm{p}$ (16 uker) (Miller et al., 2007). Studier uten kontrollgruppe har vist lovende resultater i bl.a. å redusere selvskadingsatferd og å hindre drop-out fra behandlingen (Rathus \& Miller, 2002; Fleischhaker et al., 2006; Tørmoen et al., 2009). På bakgrunn av dette gjennomføres derfor den randomiserte, kontrollerte studien for å unders $\varnothing$ ke effekten av DBT-A sammenlignet med behandlingsom-vanlig, dvs. den behandlingen som vanligvis tilbys pasienter med gjentatt villet egenskade i en BUP-enhet. Det har ennå ikke, verken i Europa eller USA, vært gjennomf $\varnothing$ rt tilsvarende studier der effekten av DBT-A sammenlignes med standard behandling. Siden unders $\varnothing$ kelsen er den første i sitt slag, er den særlig viktig i arbeidet for å evaluere behandlingsmetoder for denne pasientgruppen.

\section{Utfallsmål}

Prosjektet vil ha et særlig fokus på å unders $\varnothing$ ke i hvilken grad behandlingen bidrar til å redusere antall nye selvskadingsepisoder etter oppstart av behandlingen. I tillegg vil man som sentrale utfallsmål unders $\varnothing$ ke alvorlighetsgrad av selvmordstanker og depresjonssymptomer, samt forekomsten av innleggelser og annen фyeblikkelig hjelp-behandling under og etter behandlingsperioden.

\section{Samarbeidsforhold}

Før inklusjon av pasienter kunne starte ble to DBT-team etablert, det ene knyttet til Ullevål US og det andre til Aker US. Femten forskningsterapeuter ble utdannet gjennom et samarbeid mellom NSSF, RBUP Øst og Sør og Linehangruppens Behaviorial Tech/Seattle i USA (se omtale av DBT-utdanning på s. 15). Fra januar 2007 ble pasienter inkludert til DBT-behandling som en del av en pilotfase, dvs. med hensikt å etablere DBTkompetanse med høy kvalitet i de to teamene samt å sørge for at behandlingsprogrammet kunne innpasses i BUP-enes samlede behandlingstilbud på en smidig måte. Parallelt ble det etablert et system for adherens-koding - det vil si et system for å kvalitetssikre at DBT gis i henhold til manualen ved å vurdere et tilfeldig utvalg av videotapete terapiseanser som blir gitt i behandlingsprogrammet.

Til dette formålet har Linehan-gruppen utviklet et eget instrument som i korte trekk skårer den enkelte DBT-terapeuts evne til å gi behandlingen slik den er forutsatt å gis. En adherens-koder ble utdannet, også dette i samarbeid med BehaviorialTech/Linehan-gruppen.

Opprinnelig var det tenkt at prosjektet skulle gjennomføres som en multisenterstudie med samarbeid med poliklinikker i Trondheim, Oslo og Bergen. For å kunne håndtere utfordringer mht bl.a. datainnsamling, kvalitetssikring av behandling og inklusjon besluttet man imidlertid å lokalisere prosjektet til et mer avgrenset geografisk område. Samarbeidsavtaler ble så inngått med ni BUP-er i Oslo og Akershus. Det er etablert et særlig nært og forpliktende samarbeid med de fem BUP-ene som har DBT-team (poliklinikker under daværende Ullevål US og Aker US). Samarbeidet innebærer i hovedsak inklusjon av pasienter, at BUPene gir behandling til inkluderte pasienter, og at prosjektgruppen ved NSSF følger opp datainnsamling med hver enkelt pasient.

\section{Kontakt prosjektet}

Hovedkriteriene for å kunne delta i prosjektet er alder 12-18 år og gjentatt villet egenskade.

Helsepersonell i Oslo og Akershus som i kommer i kontakt med ungdom som skader seg selv, kan ta kontakt prosjektkoordinator

Egil Haga (tlf. 229234 42) for spørsmål om henvisning til prosjektet. 


\section{Rekruttering av pasienter}

Siden oppstart er 27 pasienter inkludert i pilotdelen av prosjektet og fått DBTbehandling.

I den randomiserte, kontrollerte studien skal 80 pasienter inkluderes, og inklusjonsperioden er planlagt å vare fram til august 2011. Det er nå inkludert 39 pasienter til denne delen av prosjektet.

Siden pilotfasen av prosjektet er det gjort et mangesidig og kontinuerlig arbeid for å sikre rekruttering av pasienter til prosjektet. Man antok tidlig at det ville være nødvendig å være svært aktive i rekrutteringsarbeidet. For å kunne komme i kontakt med så mange aktuelle, nyhenviste pasienter som mulig, og for i tillegg å komme i kontakt med dem i en tidlig fase i forbindelse med inntak ved BUP, ble man enige om å innføre en screeningprosedyre ved de fem BUP-ene som har DBT-team. Dette innebærer at alle ny-henviste pasienter i aldersgruppen 12-18 år skal spørres om de noen gang har skadet seg selv med vilje, evt. hvor mange ganger, og om siste episode har skjedd innenfor de siste 4 måneder (altså at selvskading fortsatt er en aktuell problemstilling).

Parallelt med dette er det etablert kontakt med skolehelsetjenesten, PPT, barneverntjenester, samt fastleger og legevaktsavdelinger i Oslo og Akershus for å informere bredt om muligheten for å henvise pasienter til prosjektet. Seminarer har vært arrangert for alle disse gruppene for å styrke deres henviserkompetanse i forhold til ungdom med villet egenskade. Man har lagt særlig vekt på å undervise primærhelsetjenesten i hvordan de kan forstå selvskadingsatferd, i viktigheten av å spørre om selvskading ved mistanke, og hvordan de kan snakke med ungdommer om selvskading. I 2009 ble også to artikler om behandling av ungdom med selvskading publisert i Tidsskrift for Den norske legeforening, og en rekke intervjuer har vært gitt i massemediene i forhold til denne problematikken.

Et eget nettsted med domenenavnet selvskading.info ble opprettet i juni 2010. Målgruppen er ungdom som skader seg selv med vilje.

\section{Nytt nettsted: www. selvskading.info}

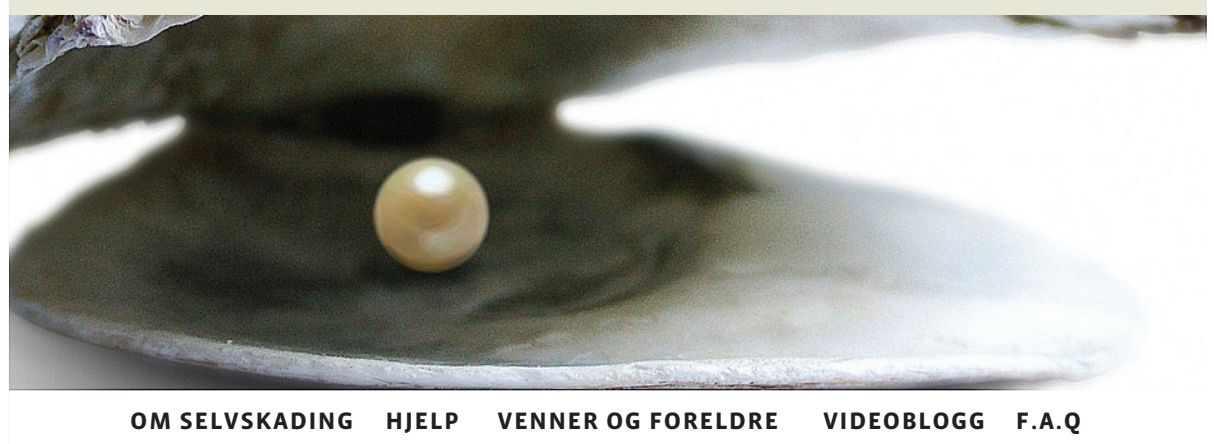

Velkommen til selvskading.info

Dette er en nettside for deg som skader deg selv med vilje. Her finner du informasjon om selvskading, og hvordan du kan få hjelp.

Selvskading.info er laget først og fremst for deg som er ung og skader deg selv med vilje, men også venner og familie av selvskadende ungdom som søker informasjon. Vi vet at svært mange ungdom som skader seg selv aldri kommer $i$ kontakt med helsepersonell. Det vil vi forandre, fordi det finnes bedre måter å håndtere det som er vondt og vanskelig enn å skade seg selv.

Nasjonalt senter for selvmordsforskning og -forebygging ved Universitetet i Oslo drifter dette nettstedet og er ansvarlig for det faglige innholdet. Hensikten er å kunne nå direkte ut til ungdom med kvalitetssikret og oppdatert informasjon om selvskading tilpasset denne målgruppen, med særlig henblikk på behandlingsmuligheter.

Egil Haga er prosjektkoordinator, og Lars Mehlum er prosjektleder for intervensjonsstudien.

\section{Referanser}

Fleischhaker, C., Munz, M., Böhme, R., Sixt, B., \& Schulz, E. (2006). Dialektisch-Behaviorale Therapie für Adoleszente (DBT-A) - Eine Pilotstudie zur Therapie von Suizidalität, Parasuzidalität und selbstverletzenden verhaltensweisen bei Pati-entinnen mit Symptomen einer Borderlinestörung. Z Kinder Jugendpsychiatr Psychother., $34(1), 15-27$

Larsson, B., Grøholt B., \& Mehlum, L.(2006).

Behandling vid upprepad självskada och suicid -försök hos tonåringar: en planerad, randomiserad och kontrollerad multicenterstudie. Suicidologi, 11(1), 16-17.

Miller, A.L, Rathus, J. \& Linehan, M.M. (2007). Dialectical behavior therapy with suicidal adolescents. New York: Guilford.
Rathus, J.H., \& Miller, A. L. (2002). Dialectical Behavior Therapy adapted for suicidal adolescents. Suicide and Life-Threatening Behavior, 32(2), 146-157.

Tørmoen, A., L. Mehlum, et al. (2009). Dialectical Behavior Therapy with suicidal and selfharming adolescents: preliminary results of a pilot study. ACBT-Conference. New York.

Ystgaard, M., Reinholdt, N. P., Husby, J., \& Mehlum, L. (2003). Villet egenskade blant ungdom. Tidsskrift for Den norske legeforening, $123,2241-5$ 